\title{
SUBJECTIVE AND OBJECTIVE IN THE NATIONAL SELF-IDENTIFICATION OF MACEDONIANS IN BULGARIA
}

\author{
Natalia BUTUSOVA \\ E-Mail: nataliabutusova@mail.ru \\ Professor, Doctor of Sciences in Law, \\ Voronezh State University, \\ Department of Constitutional and Municipal Law \\ Stojko STOJKOV \\ E-Mail: stojko.stojkov@ugd.edu.mk \\ Professor, Doctor of Sciences (History), \\ University Goce Delchev in Shtip
}

\begin{abstract}
Through the prism of "subjective" and "objective" criteria, this paper analyses the theoretical and practical problems associated with the self-identification of the Macedonians and the nonrecognition of the Macedonian minority by the Bulgarian state. Realization of the fundamental natural subjective human right to independent and free national self-identification is extremely difficult in the absence of objective conditions, such as state guarantees aimed at the development of specific national minorities. The Bulgarian state not only does not provide any guarantees for the development of the Macedonian minority, but for many decades has denied the very fact of its existence in Bulgaria, which is consistently implemented in the lawmaking and enforcement activities of this state. In result Macedonians cannot even register their own NGOs, which led to numerous decisions of ECHR against Bulgaria.The authors of the paper critically assess the Bulgarian state national ideology and politics, devoid of any signs of tolerance and not based on real, internationally recognized objective facts confirming the centuries-old existence of the Macedonian minority, the Macedonian language and culture on the territory of modern Bulgaria. In addition, the official state myths that the citizens of Bulgaria who identify themselves with the Macedonian national minority are enemies of the Bulgarian people and the state, oppose against the unity of the Bulgarian nation, have no objective basis.
\end{abstract}


The importance of international legal protection for the restoration of historical justice for the Macedonian minority and for the protection of its rights is emphasized. However, the authors regretfully note its insufficient effectiveness (in particular, none of the 14 decisions of the ECHR in favor of the Macedonian minority by Bulgaria has been implemented), and also formulate proposals aimed at increasing the effectiveness of international legal protection of the rights of the Macedonian minority in Bulgaria as an important objective condition for changing the Bulgarian national policy.

Key words: subjective and objective criteria, national selfidentification, national self-determination, Macedonian national minority, Bulgarian national ideology and politics, international legal protection.

\section{Introduction}

The constitutions of democratic states enshrine the obligation of these states to recognize and guarantee human rights, respect and protect human dignity as the highest objects of concern for state power, the most important values of modern society and the state. ${ }^{1}$ Respect for the national dignity of every person is an integral element of ideology of tolerance of European society. It is the violations of human rights, the disregard of the interests of individuals and social groups (including national interests) by the ruling elite that impede the progressive, sustainable development of peoples and states, and often become the cause of conflicts and wars.

In some European states, such as in the Baltic States and Ukraine, national minorities are not only deprived of state support for the development of national culture and language, but are forced to fight against forced assimilation. But in the $21^{\text {st }}$ century, there are still states, in particular, the Republic of Bulgaria, which do not guarantee a person belonging to a national minority, even his right to national self-identification. The official Bulgarian state has been to deny the objective fact of the very existence of Macedonians in Bulgaria for decades. The modern Bulgarian national ideology and national policy is actually based on the statement of the dictator T. Zhivkov from sixty

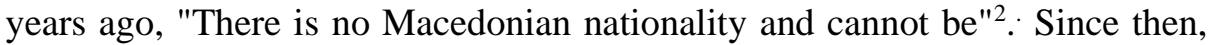
the Macedonians in Bulgaria have been referred to as "the so-called Macedonian nation." This political and ideological attitude remains in force

\footnotetext{
${ }^{1}$ Article 2 Constitution of Italian Republic 1948; article 10 Spanish Constitution1978; article 2 Constitution of Russian Federation 1993; paragraph 1, article 1 The Basic Law (Constitution) of Federal Republic of German 1949; article 7 Constitution of Switzerland 1999; 13 article Japanese Constitution 1947 etc. ${ }^{2}$ https://www.dropbox.com/s/1eqtn12n7n5zzdg/Edin_soc_naciq_11-04-89.pdf?dl=0
} 
Subjective and objective in the national self-identification...

even after the change in the social and political system of Bulgaria ${ }^{3}$. The biggest "theoretical digression" in the Bulgarian official ideology in the field of national relations, made in recent years under external pressure, was the position: "There are Macedonians, but there is no Macedonian minority."4

In a statement by the Bulgarian Parliament of March 6, 1990, in response to Yugoslavia's request to Bulgaria to recognize the Macedonian minority, it was stated that this is a "non-existent minority" and "there is no historical, legal or any other reason to seek such a minority." Until now, this position of the parliament has been consistent, implemented and publicly actively supported by the Bulgarian ruling elite in the lawmaking and law enforcement activities of the state. Nevertheless, the decision of the Constitutional Court of Bulgaria dated February 29, 2000, according to which "there is no formed Macedonian ethnos in the Republic of Bulgaria", 6 is of particular importance in this respect. This decision of the Constitutional Court was subsequently transformed into a number of court decisions in specific cases discriminating against Macedonians.

These acts created a legal basis for ideological myths denying the existence of the Macedonians as a nation and the Macedonian national minority in Bulgaria, denying the existence of the Macedonian language and culture, and also considering artificial mono-nationality, interpreted as ethnic homogeneity, as a prerequisite for state unity and national security. As a result, for six decades, several generations of Macedonians in Bulgaria have been subjected to sophisticated discrimination on the basis of ethnicity.

The reports submitted by Bulgaria to international human rights organizations on the implementation of the Framework Convention for the Protection of National Minorities traditionally exaggerate the role of "objective criteria" and underestimate the importance of "subjective" criteria. At the same time, none of Bulgaria's reports to the European Union's human rights bodies or other document sets out an official position on what the Bulgarian authorities mean by "objective criteria concerning a person's personality", in general, or in particular, in connection with the Macedonian question.

In our opinion, this issue requires a comprehensive analysis. It is necessary to reveal the content and dialectical relationship of the concepts of "subjective" and "objective" as philosophical categories, to determine their significance for the national self-identification of Macedonians in Bulgaria.

The purpose of this article is to analyse the problems of national selfidentification of citizens belonging to the Macedonian national minority in the Republic of Bulgaria from the standpoint of subjective and objective criteria and formulate proposals aimed at changing the state national ideology and

\footnotetext{
${ }^{3} \mathrm{http}: / /$ www.makedonskatribuna.com/Gotzev\%20za\%200mo\%20idrugite\%20Mt39.p df/

${ }^{4}$ URL:http://www.bghelsinki.org/bg/publikacii/digest/mikhail-ivanov/2009-06/pismodo-bhk-makedonci-u-nas-ima-makedonsko-malcinstvo-nyama/

${ }^{5}$ Rabotnichesko delo. 1990. № 66. 77 marta.p. 1.

${ }^{6}$ Dŭrzhaven vestnik. Sofiya .2000. № 18.7 marta.
} 
national policy in accordance with international legal standards and positive foreign practice in this area.

\section{Categories of "subjective" and "objective" and the right to national self-determination in Bulgaria}

The terms subjective and subjectivity reflect the ideas of a person, a thinking subject, concerning the world around him, his point of view, feelings, beliefs and desires. Whereas the concept of objective is a kind of reality that exists independently of the will, consciousness, feelings and desires of a person. If it is subjective from the word subject, i.e. depends on the perception of the subject, then the objective, from the word object, corresponds to the object, is not passed through the prism of the subject's perception. However, in philosophy attention is paid to the conventionality of differences and the inextricable connection of these concepts.

Subjective and objective are contiguous concepts, interpenetrating one another and striving to become their opposite. Although these concepts are opposite, neither of them is better or worse than the other. Artificial exaggeration of the significance of one of them distorts the actual picture of the surrounding material world. The subjective, in this case, becomes subjectivism and voluntarism, and the objective becomes objectivism (Zuev A., 2016). The complete truth can be neither only objective, nor exclusively subjective (Objectivism, p.636.)

In legal science and practice, law is traditionally distinguished in the objective and subjective sense. If objective law is legal norms aimed at regulating social relations, expressed in certain legal forms, then subjective law is those specific legal capabilities of the subject that arise based on and within the limits of objective law.

Speaking of the concept of the right to national self-determination, we note that we are talking about its understanding in the broad, objective, and narrow, subjective, sense of this concept. In a broad (objective) sense, it refers to peoples (ethnic groups) and means a system of legal norms that consolidate and guarantee the rights of peoples (nations, ethnic groups) to independently determine the form of their territorial structure and form of government, preserve and develop their national culture and language. In relation to peoples (ethnic groups), the right to national self-determination can also be considered in the broad sense of the word as a legally enshrined opportunity for the development of an ethnos (people) on the basis of the legislation of a particular state and international legal norms regulating this area.

In a narrow sense, the right to national self-determination applies to the individual: it is one of the most important subjective rights, which means the guaranteed ability of an individual to independently determine, in particular, his ethnicity ( national) identity, and also includes the right to study and use the language of a national minority, the achievements of national culture, a 
Subjective and objective in the national self-identification...

guaranteed opportunity to fully exercise political and civil rights by representatives of a particular ethnic group.

The terms "self-identification" and "self-determination" are used in constitutional law. The difference between them is that the right of selfidentification is only about the right of the person to choose to be part of one ethnos/nation, but right of self-determination include also right to freely use whole spectrum of National Minorities rights.

The human right to one's own national self-identification is one of the basic natural rights, without the realization of which the full-fledged formation and development of the individual is impossible. "Without freedom of choice, selfidentification and self-expression, without the human right to independently find and choose one's place in the world and in relation to the world, one can speak of freedom only as a fiction" (Stojkov S .Fiktsijata, p. 661).

The right of every person to national self-identification presupposes that a person is aware of his/her belonging to one or another ethnic group, to its language, history and culture, considers these as very important values and therefore strives to join the group that also identifies with these values. Paragraphs 2 and 3 of Article 1 The UN Charter ${ }^{7}$ emphasize the need to develop friendly relations between nations based on respect for the principle of equality and self-determination of peoples, respect for human rights and fundamental freedoms for all, without distinction of race, sex, language and religion. A democratic state does not grant rights but recognizes them. This duty of the state in relation to the universally recognized human rights, and therefore to the right to national self-identification, has been enshrined in a number of modern constitutions, for example, in article 2 of the Constitution of the Russian Federation; in article 2 of the Italian Constitution; in Articles 20-22 of the Constitution of the Kingdom of Spain.

The right to national self-identification is especially important for national minorities. Also, like the concept of "the right to self-determination", the term "minority" is understood ambiguously. For example, in English-language literature, there are several definitions of the concept of "minority" and they all pay attention to differences in ethnic, religious or linguistic relations. ${ }^{8}$ Some authors talk about "national" characteristics, but do not specify what the difference between the meanings of the adjectives "national" and "ethnic" is (Deschenes J.; Chernichenko S.V. Definition). The most common definition for national or ethnic minority is "a group that possesses ethnic, religious or linguistic characteristics that differ from those inherent in the rest of the population, and shows, at least indirectly, a sense of solidarity aimed at preserving their culture, traditions, religion and (or) language" (:Capotorti F. )

International organizations use different terms to refer to these minorities. In the UN, it is an "ethnic minority" (Article 27 of the International

${ }^{7}$ CM.:URL:http://www.un.org/ru/sections/un-charter/chapter-i/index.html https://www.un.org/en/sections/un-charter/chapter-i/index.html 
Covenant on Civil and Political Rights), ${ }^{9}$ and in the Council of Europe it is "national" (Article 14 of the European Convention for the Protection of Human Rights and Fundamental Freedoms). ${ }^{10}$ However, in both cases we are talking about the same characteristics: the peculiarities of language, culture, religion, and traditions. Therefore, we believe that in this context we can talk about the synonymy of the concepts of "national" and "ethnic" minority.

In the current Constitution of Bulgaria, there is no concept of "minority", national or any otherwise, although it was in the Constitution that was in force in the period from 1947 to $1971 .{ }^{11}$ And, since the Framework Convention for the Protection of National Minorities ETS No. 157, adopted in Strasbourg on February 1, 1995, ${ }^{12}$ signed by Bulgaria, deals with national, not ethnic minorities, then, according to the logic of the authorities, there is no one to apply this Convention to, since the term national minority, unlike the term ethnic minority, is not officially used by the authority. Paying attention to the fact that international legal acts do not contain an official and generally recognized definition of a national minority, the Bulgarian authorities have not formulated their own definition of this term. Nevertheless, they consider it possible to conclude that Macedonians are not a national minority.

In accordance with Article 54 (1) of the Constitution of Bulgaria, "everyone has the right to enjoy national and universal cultural values, as well as to develop his culture in accordance with his ethnicity, which is recognized and guaranteed by law (Italics added by the author) ${ }^{\prime 1} .{ }^{13}$ The fiction of Article 54 of the Bulgarian Constitution in terms of the recognition and guarantee of the rights of ethnic groups is already confirmed by the fact that in Bulgaria the absence of the definition of a national minority in international and domestic law is an argument for the official denial of the existence of minorities, such as Macedonians and Pomaks, and therefore for the non-application of the Framework Convention to them on the protection of national minorities.

In addition, this constitutional norm also leaves unanswered the extremely important, fundamental question of who determines the ethnic or national identity of a particular person. In practice, this makes it possible for the state to solve this issue. According to the constitutions of a number of states, this is the prerogative of only the person himself/herself, ${ }^{14}$ and the international

${ }^{9}$ URL: http://www.un.org/ru/documents/decl_conv/conventions/pactpol.shtml

${ }^{10}$ URL: http://base.garant.ru/2540800/\#block_100

${ }^{11}$ See: URL: http://bulgar-star.com/konstitutsiya-bolgarii ; Report by Thomas Hammarberg, Commissioner for Human Rights of the Council of Europe, following his visit to Bulgaria from 3 to 5 November 2009. URL: http://www.omoilindenpirin.org/news/2010/february27_e.asp

${ }^{12}$ URL:http://constitution.garant.ru/act/right/megdunar/2540487/ https://rm.coe.int/CoERMPublicCommonSearchServices/DisplayDCTMCon tent?documentId $=090000168007 \mathrm{cdac}$

${ }^{13}$ URL: http://bulgar-star.com/konstitutsiya-bolgarii

${ }^{14}$ See: article 6 of Constitution of Russian Federation (URL: http://www.consultant.ru ; article 19 of the Constitution of Kazakhstan Republic (URL: http://constitution.kz/ . 
Subjective and objective in the national self-identification...

legal regulation of these relations is inclined to the same conclusion. Thus, in accordance with General Recommendation No. 8 (1990) on the interpretation of article 1 of the International Convention on the Elimination of All Forms of Racial Discrimination, "national identification, if there are no grounds for the opposite, is based on the self-identification of the person concerned". ${ }^{15}$

In Russia, for example, the absence of a legislative definition of national minorities does not interfere with the realization of the rights of these minorities, since the country's national policy is aimed at the fullest possible realization of the rights of all nationalities (Trofimov E. N.) and the unity of the Russian multinational people is ensured through the development of the entire diversity of cultures of the peoples of Russia.(Butusova N. V., Zametina T. V., Stoykov S., p.p.95-96) In an additional example, in the Scandinavian countries, despite the absence of this definition in the legislation of these states, the action of the said Framework Convention also applies to groups that are usually not defined as national minorities. These examples confirm the decisive role of the state nationality policy based on a certain state ideology in the sphere of national relations, which are objective factors that have a direct impact on the possibilities of national self-identification and national development of individual citizens and entire peoples.

Undoubtedly, in states where an atmosphere of tolerance towards minorities prevails, the legalization and definition of the concept of a national minority is not necessary; however, in cases where the state and society shows a high degree of xenophobia and intolerance, a clear and unambiguous definition and inclusion of the corresponding concept in the mandatory provisions of the Constitution are an essential condition for the rights of minorities to be guaranteed. The consolidation of the concept of a national minority in international law could play a positive role in this case.

Thus, the gaps in international and national legislation allowed the Bulgarian state to form a national policy that allows the state to independently decide who is a national minority and who is not, and, consequently, to deny representatives of any nationality the exercise of their rights to selfdetermination and national self-identification. Often in such cases, the Bulgarian authorities refer to objective criteria because, in their opinion, "subjective criteria should not be decisive." 16

In this regard, it is appropriate to quote the Fourth Opinion on Bulgaria of the Advisory Committee on The Framework Convention for the Protection of National Minorities from May 26, 2020, which states: "the right to free self-

\footnotetext{
${ }^{15}$ McdugallG. Report of the independent expert on minority issues on her mission to Bulgaria (4 to 11 July 2011).UN Human Rights Council. Nineteenth session Agenda item 3. 3 January 2012. A/HRC/19/56/Add.2.\$93-95.// URL:http://www2.ohchr.org/english/bodies/hrcouncil/docs/19session/A.HR C.19.56.Add.2_en.pdf
}

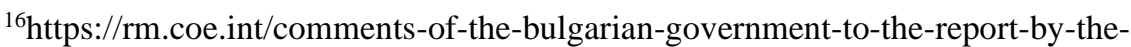
council-of-e/16809d43dd
} 
identification contained in Article 3 of the Framework Convention is not only central the provision of the Framework Convention 15, but also, according to the European Court of Human Rights, the "cornerstone" of international law in the field of the protection of minorities in general.... [L]inking the recognition of a group as a national minority with objective criteria can only be legitimate [provided that] these criteria should not be defined or interpreted in such a way as to arbitrarily limit the possibility of such recognition, and the views of persons belonging to the group in question must be accepted into consideration by the authorities when conducting their own analysis for compliance with objective criteria". ${ }^{17}$

In our opinion, the named position of the Advisory Committee reflects the actual existing dialectical relationship between subjective and objective criteria, which must be taken into account when deciding on the recognition of national minorities. History, language and culture are certainly among the objective criteria that should be considered here.

\section{History, language and culture of the Macedonians in Bulgaria as an unconditional objective criterion for its recognition as national minority}

Bulgarian citizens who identify themselves as Macedonians are not refugees, but indigenous people whose grandfathers and great-grandfathers lived on this territory. This is their homeland, no matter what it is called. Today the Republic of Macedonia is part of the historical region of Macedonia, which included, in addition to its present-day territory, Aegean Macedonia in northern Greece and Pirin Macedonia in south western Bulgaria, currently the Blagoevgrad region of Bulgaria. The formation of the modern Macedonian nation and the Macedonian language occurred in the $19^{\text {th }}$ century and took place on the territory of the historical region of Macedonia in conditions of confrontation with neighbouring states, Bulgaria, Serbia and Greece, which sought to expand their borders at the expense of the Macedonian lands. To this end, they tried to convince the Macedonian population to become part of their nations and ethnicity. In 1913, the territory of Macedonia lost by Turkey ended up within the borders of the three countries, with a small part of the lands where Macedonians were the indigenous population that became part of the newly independent Albania. (Andrew Rossos, pp.79-95).

The denial by Bulgaria, Serbia and Greece of the existence of the Macedonian nation after 1913 was a way to ensure the safety of the received territories. After the creation of the Macedonian Republic within Yugoslavia in 1944, Bulgaria and Greece gradually began to view it as a threat to their territorial integrity, and the Macedonian minorities on their territory as a

\footnotetext{
${ }^{17}$ Advisory Committee on The Framework Convention for the Protection of National Minorities: Fourth Opinion on Bulgaria, 26 May $2020 / / \mathrm{https}: / / \mathrm{rm} . c 0 e . i n t / 4$ thop-bulgaria-en/16809eb483 en/16809eb483

(https://rm.coe.int/4th-op-bulgaria-
} 
potential "fifth column". After the collapse of Yugoslavia in the new political realities, this fear has lost all real foundation, but it continues to play an important role in shaping the ideology and policy of Bulgaria and Greece.

The main part of the Bulgarian Macedonians lived and still lives in Pirin Macedonia, currentl, the Blagoevgrad region of Bulgaria. In the $20^{\text {th }}$ century, the Macedonian minority in Bulgaria was first officially recognized after 1944, but this recognition lasted no more than two decades. For less than a year, the Macedonians enjoyed limited cultural autonomy, which was eliminated after the resolution of the Information Bureau directed against Tito and Yugoslavia. (Stojkov S. Makedonskoto mal'tsinstvovo, pp. 51-52).

As for the modern Macedonian language, the existence of which is recognized throughout the world, it is still denied in Bulgaria. The process of the formation of this language was long, with the first Macedonian grammar and dictionary of the Macedonian language being published in the second half of the $19^{\text {th }}$ century, in 1875 and 1885 respectively. In 1945, after the formation of the People's Republic of Macedonia as part of Federal Yugoslavia, the Macedonian language was declared the state language along Serbo-Croatian and Slovenian. In the same year, a government decree was issued, which officially approved the codification of the Macedonian literary language. (Friedman V. A. Macedonian. pp. 435-439). The Macedonian language is studied by scientists-philologists and by students at philological faculties in many countries of the world. (Usikova R. P., pp.102-139)

When T. Zhivkov came to power, a policy of forced Bulgarianization of national minorities began. For Macedonians in Bulgaria, this was a time of repression. After 1963, hundreds of Macedonian activists, as supporters of Tito, were imprisoned, sent to camps or exiles. (Stojkov S. Tabu). In the same period, an ideological myth was formed that the Macedonian nation and the Macedonian language did not exist, and they were only a coinage of the enemies of the Bulgarian nation and state.

The fall of the communist regime in 1989 stopped the massive repression against Macedonians, but discrimination continued and the official state ideology and policy in the field of ethnic relations is still based on the statement of T. Zhivkov that the Macedonian minority in Bulgaria does not and could not exist. Discrimination against Macedonians remains, but its forms are changing, often becoming more sophisticated, ultimately aimed at assimilating Macedonians and isolating them from the cultural and political life of the Bulgarian state.

So, under a totalitarian regime, citizens who sang or listened to Macedonian patriotic folk songs were fined, threatened and beaten. Then after 1990, after the unsuccessful experience in eradicating this manifestation of national culture, Macedonian songs were declared Bulgarian. The Bulgarian state finances an entire institute, the Macedonian Scientific Institute, headed by former members of the security services, whose sole purpose is to prove that 
everything Macedonian is Bulgarian, and that the Macedonian nation, minority, language, history, and culture do not exist. ${ }^{18}$

Bulgaria has not ratified the European Charter for Regional or Minority Languages. ${ }^{19}$ Bulgaria does not introduce the study of the Macedonian language, culture and history in schools, and the official Bulgarian history studied in schools excludes any possibility of the existence of the Macedonian nation and culture. School education and the media today pursue the goal of reeducating young Macedonians and converting them to Bulgarian culture. Persons who identify themselves as Macedonians are objects of hate speech describing them as illiterate and ignorant people, traitors and enemies of the Bulgarian state and nation. Lawsuits to protect Macedonians from humiliation and insults, including those in the media, remain without satisfaction.

All methods of assimilation used by Bulgarian authority have the goal to intimidate the Macedonians ${ }^{20}$ and destroy the Macedonian language, culture and, ultimately, the Macedonian national consciousness, and through this to assimilate this national minority.

The most striking confirmation of the continued state policy of denying the existence of the Macedonian minority is the population censuses in Bulgaria. According to the census of the population of Bulgaria in the period when Macedonian minority was recognized, in 1946, there were 169,544 Macedonians, and in 1956 187,787 Macedonians, of which 178,000 lived in Pirin Macedonia. In the territory of Pirin Macedonia, $63.33 \%$ of the population were Macedonians, $33 \%$ were Bulgarians, and $3.67 \%$ were other nationalities, mainly Turks, Roma and Pomaks (Kanev K.,p. pp. 97-100)

After 1963, under the conditions of the beginning of the repressions, national identification as Macedonians was officially banned, and a separate column "Macedonian" was not provided in the census forms, which led to an artificial underestimation of their number. Thus, according to the results of the 1965 census, the number of the Macedonian population decreased from 187,787 to 9,632 . After the change in the socio-political system, but with the preservation of the old national policy, the number of Macedonians, according to the data of each subsequent census, continued to artificially decrease:

- in 1991 there were 10,803 registered Macedonians.

- in 2001 there were 5071 registered Macedonians.

\footnotetext{
${ }^{18} \mathrm{Cf}$ : Doklad za pravata na Makedontsite v Bŭlgariya. 2016, URL: http://www.omoilindenpirin.org/news/2017/may_b.asp

${ }^{19}$ URL: http://docs.cntd.ru/document/1902299

${ }^{20}$ See: "report of the Advisory Committee ... in 2014 ... observed that the long-term effect of the difficulties Macedonians experience regarding their freedom of assembly and association is to create a climate of intimidation and harassment that runs counter to convention provisions." (https://minorityrights.org/minorities/macedonians-2/)
} 
- $\quad$ in 2011 there were 1603 registered Macedonians. ${ }^{21}$

The results of the last census, in which about $10 \%$ of the population of Bulgaria did not indicate their ethnicity, and $10.4 \%$ - their mother tongue. Because of it the results were rejected by the National Statistical Institute of Bulgaria itself as unrealistic. $^{22}$ And, in preparation for the census in September 2010, Prime Minister Boyko Borisov fired 5 high-ranking officials at the National Institute of Statistics of Bulgaria because they allowed the subcategory for "non-existent ethnic groups" in the forms in the pilot census (among them, the Macedonians occupied the main place). The subcategory was removed. ${ }^{23}$

In communistic period more than hundred illegal Macedonian organizations were formed and their members were prosecuted and sand in jails.( Stojkov S. Tabu)/ In last 30 years were created several Macedonian NGOs in Bulgaria, and two parties, and today exist 9 NGO's and one political party. (Macedonians of Bulgaria, p.p.11-13). Their common goal is recognition and affirmation of Macedonian Minority in Bulgaria. To 2007 their public gatherings were prohibited, and these organizations were forced to operate without registration. Dozens of rejections of registration of these organisations led to 14 decision of ESPCH against Bulgaria. (Macedonians of Bulgaria, p.p.18-20) "Without their own party, Macedonian voters were left to choose from among other parties in Bulgaria, all of which denied the existence of a separate Macedonian identity." 24

As we can see, on the one hand, there is a subjective constant and clear desire of the Macedonians to exercise their natural right to freely determine their ethnicity, and, on the other hand, there is a subjective desire of the Bulgarian official authorities to prevent the ethnic self-identification of the Macedonians. This goal of the Bulgarian state is obvious. By what means? Under the pressure of state with threats and manipulations, artificial censuses are being conducted, where data on the real national composition of the population of Bulgaria is falsified. People are recorded as Bulgarians or with no ethnicity, and the numbers of national minorities are decimated, especially Macedonians. Of course, this activity of the state for the Macedonian minority is an objective factor that creates insurmountable obstacles to their self-realization and development.

Under pressure from outside, the Bulgarian authorities from time to time declare that everyone has the right to ethnic self-determination, but in practice, in particular during the population census, these authorities demonstrate disrespect for the self-determination of thousands of Macedonians. They do not even demonstrate respect for these manipulated results of the censuses, which

\footnotetext{
${ }^{21}$ https://minorityrights.org/minorities/macedonians-2/, Macedonians of Bulgaria, Minorities in Southeastern Europe, Center of information and documentation of Minorities in Europe - Southeastern Europe, p. 9

${ }^{22}$ Cf. URL: Final Fourth Opinion on Bulgaria - adopted on 26 May 2020 https://rm.coe.int/4th-op-bulgaria-en/16809eb483, \& 30

${ }^{23}$ Cf.: Report on the Census in Bulgaria. 2011. P. 10. URL: http://www.omoilindenpirin.org/documents/report.pdf

${ }^{24} \mathrm{https} / / /$ minorityrights.org/minorities/macedonians-2/
} 
still registered thousands of Macedonians. Since the official position remains that there is no Macedonian minority in Bulgaria, this, in turn, is the basis for a serial court verdict depriving Macedonians of the right to create their own NGOs. ${ }^{25}$

\section{Subjective and objective conditions for the participation of Bulgarian citizens of Macedonian nationality in the social and political life of Bulgaria}

Active participation of citizens in the social and political life of the country is an essential feature of a democratic state. The subjective condition for active political participation is the activity of citizens themselves. Objective conditions are intended to create the guaranteeing activity of the state, and international legal protection can also play an important role in this regard. An important form of political participation and, at the same time, a condition for the active use of other forms of democracy, is the creation and operation of public organizations. For effective management of society and state, it is necessary to ensure proper guarantees for the activities of public and nongovernmental organizations capable of providing feedback between citizens, civil society and the state.

After the fall of the communist regime, Macedonians in Bulgaria started to create parties and public organizations, which envisage in their statutes only cultural, educational and human rights goals in full compliance with Bulgarian legislation. Today, there is really only one political party representing Macedonian Minority (the United Macedonian organization "Ilinden" - PIRIN, hereinafter OMO "Ilinden" - PIRIN), which defines its goals and objectives within the framework of the Bulgarian political and legal system. The same party acts as the Coordination Center for Macedonian organizations in Bulgaria. The demands of the Macedonian movement are to end the denial, discrimination and forced assimilation of the Macedonian minority in Bulgaria and to obtain the rights provided for by the Framework Convention for the Protection of National Minorities. The public activities of Macedonian parties and organizations, which were prohibited until 2007 , are currently permitted and actually consist in the organization of cultural, historical celebrations and gatherings, sports competitions, scientific meetings, publication of newspapers and books, attempts to participate in elections, in the preparation of annual and special reports on the rights of the Macedonian minority in Bulgaria, as well as in solving urgent problems of the citizens of Bulgaria, who are also the Macedonians living there (S. Stojkov, N. Butusova, 2018, p.26-28). But, registration of these organizations is not permitted, and they continued to operate without registration.

Bulgaria claims that these organizations would undermine the government, but over the past three decades, neither the political party, nor any

\footnotetext{
${ }^{25}$ See: Verdict № 1 from 29th February 2000 about the Constitutional Case \#3 of 1999 "In the Republic of Bulgaria there is no separate Macedonian ethnos." // Published in State newspaper № 18, 07.03.2000, etc.
} 
of the Macedonian organizations in Bulgaria supported actions that could be interpreted as separatist or endangering the national security of Bulgaria, as confirmed by the Committee of Ministers of the Council of Europe on June 8, $2007 .{ }^{26}$ In fact, the desire of all Macedonian organizations to register clearly indicates that they respect the Bulgarian legal system and intend to work within this framework. The lack of registration of Macedonian organizations seriously limits their opportunities in the field of civil law relations, makes it impossible to work on national and international projects, and prevents partnerships with government agencies and their participation in elections.

Despite all the efforts made on their part, nearly all Macedonian political parties and NGOs have been rejected from registration, and the only three that were registered were immediately put in procedure for deregistration from the state. Over the past 20 years, Bulgarian national courts have suppressed more than 20 attempts for registration of Macedonian parties and organizations. ${ }^{27}$ Even the democratic principle of equality of citizens, regardless of any discriminatory grounds (Article 6 (2) of the Constitution of Bulgaria), is often used as a ground for refusing to register Macedonian organizations, since they, taking care of the rights of Macedonians, pose a threat to the rights of the majority of citizens (S. Stojkov, N. Butusova, 2018, p. 2223).

The unjustified refusal of the Bulgarian courts to register Macedonian organizations has repeatedly been the subject of discussion in the Committee of Ministers of the Council of Europe (hereinafter also referred to as the Committee of Ministers). The Committee of Ministers considered this issue at its meeting in December 2014 after the ECHR made another decision in favor of Macedonian organizations in connection with the refusal to register the OMO Ilinden. The Committee of Ministers began to conduct enhanced monitoring and established control over Bulgaria in order to solve this problem (S. Stojkov, N. Butusova, 2018, p. 29).

However, this problem has not yet been resolved. Bulgaria has never fully implemented any of the ECtHR judgments in favor of the Macedonian minority, concerning registrations of Macedonian NGOs, despite the fact that there are already 14 verdicts against Bulgaria. As noted in the Resolution of the Committee of Ministers of October 1, 2020, dedicated to the execution of judgments of the ECHR: "since 2006, associations similar to 'UMO Ilinden' have been refused registration on a number of occasions on grounds, such as the potential for an association promoting the existence of a "Macedonian minority" to endanger national unity and the constitutional prohibition on associations pursuing political goals, which have been systematically rejected by the European Court in the cases from this group". The Committee of Ministers "exhorted the authorities to ensure that any new registration request

\footnotetext{
${ }^{26}$ URL: http://www.omoilindenpirin.org/news/2007/june08_e.asp

${ }^{27}$ For example in the period 2006 - 2008 courts three times refused registration of OMO Ïlinden"-PIRIN
} 
of 'UMO Ilinden' or associations similar to 'UMO Ilinden' is examined in full compliance with Article 11 of the Convention" 28 .

Unfortunately, the international legal protection of the Macedonian minority in Bulgaria cannot be recognized as effective. Special bodies designed to protect the rights of minorities in Bulgaria, created under the influence of international organizations, primarily through the Council of Europe and the European Union, are always inactive. ${ }^{29}$ The official authorities of Bulgaria are pursuing a policy of ignoring the recommendations of international institutions to end discrimination against the Macedonian minority, dialogue with its representatives, including a series of unimplemented decisions of the ECHR against Bulgaria in connection with the violation of the rights of Macedonians to organize and hold assemblies ${ }^{30}$.

However, one cannot but admit the increased activity of international bodies on the issue of protecting the rights of the Macedonian minority in recent years. In 2020, the recommendations to Bulgarian authorities have become far more explicit. On June 26, 2020, the Advisory Committee referring to Macedonians and Pomaks "reiterates its urgent call on the authorities to enter into a dialogue with groups having expressed an interest in the protection afforded by the Framework Convention and to consider the possibility of applying its provisions to persons belonging to such groups on an article-byarticle basis." 31 On August 28, 2020, the Democracy, Rule of Law and Fundamental Rights Monitoring Group in the European Parliament asked the Bulgarian government about "the attempts to hinder the work of e.g. NGOs working with the Macedonian-Bulgarian minority (deregistering and NGO)". ${ }^{32}$ On October 1, 2020, the Committee of Ministers urged Bulgarian authorities "that associations aiming to achieve 'the recognition of the Macedonian minority in Bulgaria' should not be refused registration on grounds related to the associations' goals and means for pursuing them which contradict the European Court's judgments in these cases, and that such associations should not be subject to dissolution procedures on similar grounds". ${ }^{33}$ On the same day, the European parliament adopted the Resolution for Bulgaria in which it urged authorities "to take all the necessary measures to safeguard the rights of minorities effectively, in particular the rights to freedom of expression and freedom of association, including through implementation of the relevant

\footnotetext{
${ }^{28}$ URL: https://search.coe.int/cm/pages/result_details.aspx ?ObjectId=09000016809fc5 87

${ }^{29}$ These are the National Council for Cooperation in Ethnic and Integration Issues, the Commission on Protection against Discrimination, as well as the Ombudsman.

${ }^{30}$ Article 11 of the Convention on the Protection of Human Rights and fundamental freedoms.

${ }^{31} \mathrm{https}: / / \mathrm{rm}$. coe.int/4th-op-bulgaria-en/16809eb483

${ }^{32} \mathrm{https} / / /$ www.europarl.europa.eu/cmsdata/211284/DRFMG\%20questions\%20to\%20 Bulgarian\%20authorities.pdf

${ }^{33}$ https://search.coe.int/cm/pages/result_details.aspx ObjectId=09000016809fc587
} 
Subjective and objective in the national self-identification...

judgments of the European Court of Human Rights" referring directly to the ECHR decisions about Macedonian NGOs. ${ }^{34}$

Apparently, an increase in the effectiveness of the international legal protection of the rights of the Macedonian minority in Bulgaria as an important objective condition for the participation of Bulgarian Macedonians in the social and political life of Bulgaria, as well as for a change of the Bulgarian national policy, would be facilitated by a more consistent position on a number of issues of the ECHR, as well as other bodies, included in the international legal system of the protection of human rights. In particular, it is evident that the reluctance of the ECHR to admit that in cases of violation of the rights of Macedonians to register their organizations, among other things, represents discrimination on the basis of ethnicity. In addition, the European human rights bodies avoidance of the use of the term "Macedonian minority" is, in our opinion, an indication of excessive caution.

\section{Conclusion}

The history of the Macedonians is not the only example in the history of peoples, nationalities, or ethnic groups, who, as a result of geopolitical changes, turned into national minorities in the territory of other states.

The recognition of the Macedonian national minority in Bulgaria, as emphasized in this article, is a defining condition for ensuring the full range of human rights for those who identify themselves with the Macedonian ethnos, nationality. First of all, we are talking about the right to respect for the national dignity of the individual, the right to national self-identification, the right to develop national culture, language. An analysis of the problems of realizing the right to national self-identification of Macedonians in Bulgaria through the prism of the categories of "subjective" and "objective" made it possible to draw the following conclusions:

- The denial of the existence of the Macedonian minority by the Bulgarian official authorities is a manifestation of subjectivity, absolutely not based on objective facts recognized throughout the world.

- The Bulgarian national ideology and national policy are devoid of any signs of European tolerance, they have deformed the life of several generations of Macedonians, ignored the positive foreign experience in the development and functioning of interethnic relations. The aforementioned ideology is based on ideological ideas and phantom fears that have no real basis in the longchanged socio-political conditions.

- As emphasized in numerous decisions of the ECHR and recommendations of international organizations, the unity of the nation is achieved not through artificial one-nationality, but as a result of the consistent guaranteeing of the rights of all nationalities, ethnic groups, and primarily the right to free national self-identification. A wise state policy is needed, aimed at

${ }^{34}$ https://www.europarl.europa.eu/doceo/document/B-9-2020-0309_EN.html 
ensuring consensus as one of the conditions for social peace and prosperity of the whole society, after all, as the English proverb says, "no sense walking away from a good thing".

-Although international legal protection of National Minorities is carried out regardless of the recognition of national minorities by the state, we believe that increasing the effectiveness of international protection of the Macedonian minority in Bulgaria could become an objective factor contributing to state recognition of Ethnic Macedonians, and perhaps would eliminate the need for their international legal protection in future.

- In order to increase the effectiveness of international legal protection of national minorities, we consider it necessary to consolidate the concept of "national" or "ethnic" minorities at the international level. Moreover, this definition should include mandatory criteria related to history, language, culture, as well as, possibly, dispositive criteria, at the discretion of states.

- Non-implementation by Bulgaria as a member of the European Community of 14 ECtHR judgments on the Macedonian cases discredits the ECHR and European system for the protection of human rights itself. The creation of a reliable objective basis for changing this situation, in our opinion, would be facilitated by a more consistent position of the ECHR itself and other European human rights bodies, which in their official documents unreasonably avoid using the phrase "Macedonian national minority" and do not directly recognize the facts of discrimination of this minority on national sign. 
Subjective and objective in the national self-identification...

\section{References}

Butusova N. V., Zametina T. V., Stoykov S. Gosudarstvennaya natsional'naya politika kak garantiya natsional'nogo samoopredeleniya (na primere Rossii i Bolgarii) [State Ethnic Policy as the Guarantee of National SelfDetermination (on the Example of Russia and Bulgaria)] //. Sovremennoe obshchestvo i parvo,2016, no. 2, pp. 95-96. (in Russian).

Capotorti F. Study on the Rights of Persons belonging to Ethnic, Religious and Linguistic Minorities. New York: United Nation, 1979.

Chernichenko S.V. Definition of Minorities. Second working paper. E/CN4?sub2/AC5/1997/WP1. 2 april 1997, annex: Minorities - a working definition: article $1 . \quad$ URL: http://oppenheimer.mcgill.ca/IMG/pdf/definitions_droit_des_minorite s_ethniques.pdf (accessed: 05.09.2020).

Deschenes J. Proposal concerning a definition of the term "minority". E.CN4/sub2/1985/31. Geneva : United Nation, 14 May 1985// URL: http://oppenheimer.mcgill.ca/IMG/pdf/definitions_droit_des_minorite s_ethniques.pdf (accessed: 05.03.2018).

Fomichenko M. P. Zashchita prav narodov v Rossiyskoy Federatsii (konstitutsionno-pravovyeaspekty)[Protection of the rights of peoples in the Russian Federation (constitutional and legal aspects)], Moscow: Izdatel'stvo RGSU. 2005 (in Russian).

Friedman V. A. Macedonian. In: Garry J. and Rubino C. (eds.) Facts About the World's Languages: An Encyclopedia of the World's Major Languages, Past and Present, New York, Dublin: A New England Publish Associates Book, 2001. pp. 435-439;

Kanev K. Zakonodatel'stvoipolitika km etnicheskite i religioznimaltsinstva $\mathrm{v}$ Blgariya [Legislation and Policy towards Ethnic and Religious Minorities in Bulgaria]. In: Obshchnosti I identichnosti v Blgariya [Communities and identities in Bulgaria],Sofiya: Petekston. 1998, pp. 97-100. (in Bulgarian).

Macedonians of Bulgaria, Minorities in Southeastern Europe, Center of information and documentation of Minorities in Europe - Southeastern Europe, p. https://issuu.com/sonjcemarceva/docs/macedonians_of_bulgaria (visited on 13.12.2020)

Marinov C.H. Makedonskoto prashan'e od 1944 do denes: komunizmot I natsiona-lizmot na Balkanot [The Macedonian question from 1944 to the present, Communism and nationalism in the Balkans], Skop'e.2013(in Macedonian).

Objectivism. [Entsiklopedicheskiy slovar' Brokgauza i Yefrona: v 86 tomakh. Vol. XXIA. (42). - SPb., 1890-1907). S.636.) Encyclopedic Dictionary of Brockhaus and Efron: in 86 volumes. Vol. XXIA. (42). - SPb., 18901907). P.636.). (in Russian). 
Rossos Andrew, Macedonian and the Macedonians, A history, Studies of nationalities, Hoover institution press, Stanford University. California, 2008 . pp. 435-439.

Stojkov S., ButusovaN. O problemakh garantirovaniya prav makedonskogo natsional'nogo men'shinstva $\mathrm{v}$ Bolgarii . [On the problems of guaranteeing the rights of the Macedonian national minority in Bulgaria]//Comparative constitutional review.2018. № 3 (124). Pp. 15-32. (in Russian).

Stojkov S. Fiktsiata na obektivnite kriteriumi protiv pravoto na samoopredeluvan'e: primerot na makedonskoto maltsinstvo vo Bugaria [Fiction of objective criteria against the right to self-determination, the example of the Macedonian minority in Bulgaria]. In: Opshtestvenite promeni vo globalniot svet: zbornik na nauchni trudovi. Vtora megunarodna nauchna konferentsija [Social changes in the global world: Collection of scientific papers. Second International scientific Conference], Stip: UniversitetGoceDelcev, 2015 pp. 659-675. (in Macedonian).

Stojkov S. Makedonskoto mal'tsinstvovo Bugarija I nemokta na megunarodniot pravozashtiten system [The Macedonian minority in Bulgaria and the weakness of the international human rights system]. In: Butusova N.V., Ananieva Y. (eds.) CHelovek $\mathrm{v}$ global'nom mire: materialy Mezhdunarodnoy nauchnoy konferentsii [People in the global world: proceedings of The International scientific Conference], Voronezh: Izdatel'skiydom VGU. 2015. pp.49-53. (in Macedonian).

Stojkov S. Tabu - vreme na strakh I stradanie. Presledvaneto na makedontsite v Blgariya po vreme na komunizma (1944 - 1989) [Taboo - a time of fear and suffering. The Persecution of the Macedonians in Bulgaria during the Communism (1944 - 1989)], Blagoevgrad: Druzhestvo na represiranite makedontsi v Blgariya. 2014.(in Bulgarian).

Stojkov S. Persecution of "Non-Existent": Repression of Macedonians in Bulgaria during the Communist Period (1944 - 1989), in: Macedonia $\&$ its Questions, Studies on Language and Culture in Central and Eastern Europe 34, Peter Lang, Berlin, 2000. pp. (205 - 255).

Trofimov E. N. Natsional'nya politika Rossii (zakonodatel'nyy aspekt) [National policy of Russia (legislative aspect)], Moscow: Izdatel'stvo RAGS. 2007.( in Russian).

Usikova R. P. YUzhnoslavyanskie yazyki. Makedonskiy yazyk [South-Slavic languages. Macedonian language]. YAzykimira. Slavyanskieyazyki [Languages of the world. Slavic languages], Moscow: Academia. 2005. pp. (102-139) (in Russian).

Zuev A. Ponyatiye sub"yektivnoye i ob"yektivnoye [The concept of subjective and objective] //https://proza.ru/2016/03/28/2428 (Accessed 29.09.2020) 